\title{
Islamic Microfinance in Sudanese Perspective
}

\author{
Elsadig Musa Ahmed ${ }^{1}$ and Anwar Ammar² \\ ${ }^{1}$ Faculty of Business, Multimedia University, Cyberjaya, Malaysia \\ ${ }^{2}$ Faculty of Management, Multimedia University, Cyberjaya, Malaysia
}

\begin{abstract}
Microfinance-providing affordable financial services to the poor- has been identified as an important tool in increasing the productivity of the poor and in enhancing economic development. Although conventional microfinance products have been very successful in Muslim countries the traditional microfinance contract which involves the payment of interest (riba) is strictly prohibited with the principles set forth in the Sharia of Islam. Sharia-compliant microfinance is one among many interventions designed to bring poor people into the formal financial mainstream. Islamic microfinance leaders have taken the initiatives to meet the increasing needs of the poor Muslim customers with the aim of alleviating poverty among poor Muslim people. While conventional microfinance institutions (MFIs) have expanded their operations in the last two decades, Islamic microfinance products are still quite small relative to the conventional microfinance sector. Sudan emerges as the most prominent market for Islamic banking in terms of number of Islamic banking providers. This is driven by the fact that the country requires full compliance with Sharia principles for the entire financial system. In this respect, the aim of this paper is to shed light on Islamic microfinance in Sudan.
\end{abstract}

Keywords: Islamic microfinance; Sharia-compliant; Sudan

\section{Introduction}

Sudan a country with a population of approximately 36.2 million, of which two-thirds is rural, holds abundant land and livestock, rich mineral resources and, solid manufacturing base. Despite these large endowments of natural resources, and its agricultural potential; Sudan is ranked the fifth hungriest nation in the world by the Global Hunger Index. "Much of this potential has not been realized due to longrunning conflict and governance challenges; and the gains of the last growth decade have not advanced productive public investment that contributes to poverty reduction, or been widely shared [1].

The Sudanese economy is witnessing a crucial downturn since the separation of the south in 2011; Sudan loosed 75\% of its oil revenue due to this secession. Growth rate of the country's GDP show declines from $3.5 \%$ in 2010 to $-3.3 \%$ and $-10.1 \%$ in 2011 and 2012 , respectively (WDI) [2]. This is reflected on the livelihoods of many Sudanese in forms of increasing poverty statistics. Average rural poverty rates in Sudan are estimated at $58 \%$, much higher than the national average and the urban poverty rate ( $47 \%$ and $27 \%$, respectively) (National Baseline Household Survey [NBHS]. The main constraints on rural livelihoods are poor access to markets, lack of access to financial services. Unemployment is also high (19.8\%) in rural than in urban (12.1\%) areas (FAO 2015) Other factor contributed to the unemployment and poverty is longest civil wars and the internal conflicts across the regions.

Promotion of economic growth, reduction of poverty, achieving MDGs (Millennium Development Goals) and employment creation are among the first important policy priorities and strategy pillars of the Government of Sudan to address the challenges of high poverty, unemployment, an increase of inflation due to the secession of the South in 2011.Within this context and as articulated in theInterim Poverty Reduction Strategy Paper IPRSP for Sudan, microfinance is one of the major tools which is given due priority by the government to alleviate poverty particularly in marginalized and conflict areas [3].

\section{Islamic Microfinance}

Earlier studies of the application of Islamic finance in microfinance was carried by Rahul and Sapcanin cited by Khan [4] they demonstrate that Islamic banking, with its emphasis on risk sharing for certain products and collateral-free loans, is compatible with the needs of some micro-entrepreneurs. Islamic Microfinance is very effective and essential for creating hope for the poor and those above the poverty line as shown by the traditional microfinance, but also for the extremely poor in the community the Islamic microfinance, based on a partnership mode, is fair and does not require poor clients' payment, or lead to a loss of the livelihood of the poor in the case of project failure beyond the client's control. It also does not require strong guarantees [5]. Viable projects that are rejected by conventional lending institutions because of insufficient collateral might prove to be acceptable to Islamic banks on a profit-sharing basis. Poor Muslims remained excluded from traditional microfinance for several reasons, voluntarily due to the practices of the interest rate by conventional lending institutions which considered riba, can be excluded nonvoluntarily due to inability to repay back the loan plus the interest rate accrued to it. Hence, Islamic microfinance can easily overcome these challenges due to its wide scope to cover various diversity of customer whether based on their expertise or sectorial dimension.

On the funding side, Islamic microfinance services providers can mobilize additional resources through zakat (Zakah is instruments of charity occupy a central position in the Islamic scheme of poverty alleviation) and waqf (Waqf is a trust or pious foundation), and on the lending side they mainly use financial instruments that are based on Profit and Loss Sharing (PLS) schemes such as mudarabah and musharaka (Musharaka and mudaraba are contracts which share risks and benefits) rather than loans. Qard-al-Hassan (Qard-al-Hassan is an interest-free loan that the Qur'an encourages Muslims to make to the needy) resources should be made available to Islamic microfinance

*Corresponding author: Elsadig Musa Ahmed, Faculty of Management Multimedia University, Cyberjaya, Malaysia, E-mail: elsadig1965@gmail.com

Received June 23, 2015; Accepted August 14, 2015; Published September 30 , 2015

Citation: Ahmed EM, Ammar A (2015) Islamic Microfinance in Sudanese Perspective. J Bus Fin Aff 4: 149. doi:10.4172/2167-0234.1000149

Copyright: @ 2015 Ahmed EM, et al. This is an open-access article distributed under the terms of the Creative Commons Attribution License, which permits unrestricted use, distribution, and reproduction in any medium, provided the original author and source are credited. 
institutions to reduce the burden of high interest charges on their borrowers Zakat funds could be used to cover the default risk of microenterprises and to build capacity and skills. Takaful (Takaful is a mutual insurance) - micro-insurance - can be used for protection against unpredicted risks by borrowers. Murabaha (Murabaha is a "cost plus markup" sale contract) sale is used to finance goods. Salam is an advance payment in exchange of a future delivery, and istisna the exchange contract between a seller and a buyer.

Many studies show that poor Muslims refrain from taking interest-based microfinance products due to religious beliefs [4,68]. Salwana et al. [9] study revealed that traditional microfinance has failed to satisfy the Muslims communities because of its shift from poverty to focus on profit oriented business. Riwajanti [10] suggests that Islamic Microfinance should be considered contributing to poverty alleviation, financial development, and also financial inclusion because it offers unique characteristics with rich of values and human oriented. Shabrawy [11] favours the Islamic Microfinance because risk is shared between financial institutions and beneficiaries, allowing the entrepreneurs to concentrate on what they do best. A survey conducted in Azad Kashmir Pakistan by Al Huda Centre of Islamic Banking and Economics in 2011, exhibited that $99 \%$ of respondents showed strong demand for Islamic microfinance services [12].

\section{Islamic microfinance in Sudan}

Islamic microfinance is one of the essential unconventional outlets of lending that use by Islamic financial institutions to relieve the negative impact of the extreme poverty and unemployment among the people in Muslim countries. Being the majority are Muslims and more than 35 Islamic banks in addition to others non- banks Islamic financing providers, the country has become a suitable host for Islamic microfinance.

Microfinance existed in Sudan for decades as an informal economic activity. Traditionally villagers borrowed from local merchants in cash or in-kind consumption or emergency loans and paid back the loan when their anticipated funds become available. Microfinance was officially formalized by Bank of Sudan when it recognized Micro entrepreneurs and micro-enterprises in 1990 and included Artisan and skilled workers among the priority sectors to receive finance from commercial banks, especially for projects in rural areas. In 1994, micro-enterprises and low-income productive families were added together with agriculture, manufacturing, exports, mining, power generation, low cost housing, transport, and warehousing as priority sectors to receive finance from commercial banks. Social funds and donor supported programs have also been in operation for quite a while and many communities have benefited from their contributions. Islamic financial infrastructure has witnessed tremendous growth and improvement since 1989. The government transformed the existing dual economic system into Islamic financial system. This initiative has improved Islamic financial infrastructures and made enabling environment for Islamic microfinance.

Central Bank of Sudan (CBOS) in 2006, took the initiative of formulating a vision for developing and expanding microfinance sector in Sudan [13]. The vision detailed the creation of a conducive legal environment by: reviewing current law and policies of the CBOS to encourage banks to provide micro financing through i) monetary and flexible pricing policy, ii) restructuring and of some specialized bank like the Savings and Social Development Bank, and the Agriculture Bank of Sudan, iii) improving outreach of financial institutions though more bank branches and downscaling, iv) licensing of MFIs. The vision specified the requirements for a regulatory framework such as minimum capital requirements, capital adequacy, loan provisioning etc. in order to expand the financial resources. The vision also called for wholesale lending by banks to MFIs. Diversification of products and services including making use of traditional modes of finance and setting conducive modes of investments was emphasized in the vision. Institutionally; the vision called for the establishment of a MF Unit at the CBOS for regulating, supervising and promoting the development of micro finance and establishing an Apex institution outside CBOS to help in coordination among all stakeholders.

Since 2007 , the policies issued annually by the CBOS incorporated specific section on microfinance. The CBOS started gradually to develop an enabling policy environment for microfinance adding elements that addresses constraints facing the sector from year to year. The major CBOS polices encompassed establishing a special MFU in CBOS to regulate, develop and supervise microfinance, encouraging banks to allocate specific resources to microfinance, resolving guarantees issues, allowing diversified Islamic modes of finance that are suitable for microfinance, developing wholesale financing and encouraging intermediaries and support services [14].

\section{Microfinance providers}

Total windows serving microfinance, both provisions of financial and non-financial services all over the country amount to 501 windows of which 466 are financial services windows and 35 windows are non-financial services. For financial services, it was found that micro are being provided by 21 banks (representing 54\% of the operating banks) through 286 service windows, (i.e. $47 \%$ of the total branches providing banking services); a total number of 27 MFIs operating and under establishment through 37 windows; 18 mediators delivering their services through 87 windows (double number of the specialized MFIs windows); 33 windows of social security institutions and 23 supervision institutions. Non-financial micro financing services are provided by about 35 institutions of which: 4 are training and capacity building centres, 19 are technical support and development of small scale projects, 6 are consultancy firms and 6 are specialized collages. This is beside the informal sector spreading all over the country [3].

\section{Outreach}

Outreach is an important aspect of microfinance in view of the fact that the fundamental aim of microfinance is to reach the largest number of unnerved poor people who do not have access to financial services. Limited outreach can impact on the sustainability in terms of benefits linked to economies of scale.

The capacity of providers is very far from meeting the demand for this service. Potential microfinance customers in the country may exceed 8 million individuals, while coverage as shown by the number of clients of the microfinance services providers by this study hardly exceeds 350,000. Even discrepancies exist in the distribution between the state and between urban and rural. Most of the service providers are concentrated in the states with the lower poverty rates and are less in poverty stricken states, contrary to the policy and rationale that was behind the support for micro financing. Most windows are not in rural areas. There is only one rural micro finance service provider in all states out of 48 representing only $2 \%$ [14].

The number of clients (Banks and MFIs) increased from 244,000 in 2011 to 494,000 in 2012 and to 700,000 in 2013further to 970,000 in mid-2014, the banking MF portfolio increased from $1 \%$ in 2007 to $5 \%$ in 2013, MFIs increased from 3 in 2007 to 23 in 2013, The 
MFIs' Non-Performing Loan NPL down from 6\% in 2012 to $1.9 \%$ in 2013. According to IMF (2013) the number of MF borrowers went from 49,000 at end-2007 to 494,000 by 2012 . The growth has occurred in both bank portfolios $(49,000$ to 300,000$)$ and at the dedicated MF institutions (zero to 194,000) [15].

\section{Penetration}

UNICONS [16] study indicates that microloans are concentrated in urban areas; Microfinance Providers MFPs are far from achieving the CBOS directive for channelling $70 \%$ of their MF loans to rural areas. The Mapping (2012) shows that total windows serving microfinance, both provision of financial and non-financial services all over the country amount to 501 windows of which 466 are financial services windows and 35 windows are non-financial services. For financial services, it was found that microfinance are being provided by 21 banks (representing $54 \%$ of the operating banks) through 286 service windows, (i.e., $47 \%$ of the total branches providing banking services); a total number of 33 MFIs operating and under establishment through 37 windows; 18 mediators delivering their services through 87 windows (double number of the specialized MFIs windows); 33 windows of social security institutions and 23 supervision institutions. Non-financial microfinance services (Training and capacity building; Technical support, and consultation) are provided by about 35 institutions of which: 4 are training and capacity building centres, 19 are technical support and development of small scale projects, 6 are consultancy firms and 6 are specialized collages.

\section{Sudan microfinance experience}

The Sudanese experience showed that Islamic microfinance has a positive impact on income generating activities. Agricultural Bank of Sudan Microfinance Initiative (ABSUMI) Offer shariacompliant credit, savings and micro insurance, particularly to women, ABSUMI was supported by three key stakeholders: the IFAD-funded Western Sudan Resources management Programme, ABS and the Microfinance Unit of the Central Bank of Sudan. As of May 2012, ABSUMI had reached 36,000 members of 6,000 households through 350 women's groups. It had mobilized savings worth US $\$ 72,000$ with a client base of 4,500 borrowers and a loan portfolio of US\$700,000. Its loans based on murabaha and musharaka are supporting small agricultural activities, livestock fattening and rearing, and a range of microenterprises such as petty trading, tea stalls and brick-making (IFAD [17]. Impact Evaluation ( 2013) study show that microfinance clients respondents reported an improvement in nutrition for their families ( $46.7 \%$ of clients), followed by better access to education (36.3\%), better access to health services (33.8\%), and purchase of property $(30 \%)$. When compared to non-clients, less impact is reported by non-clients in all areas. Amira [18] study main findings revealed that participation of women in micro-credit program helps in promoting women's empowerment, in particular the economic and socio cultural dimensions of empowerment. The targeted women became economically empowered by (1) having their own income, (2) contributing to household purchases and (3) financing the education of their children; however, they did not manage to make savings to promote their micro-small operations. Fadul et al. [19] study impact of microfinance in North Kordofan, Sudan, results of the descriptive statistics show that there is a positive effect of microfinance on poverty reduction by $16 \%$. Microfinance institutions enable poor low-income households to develop their microenterprises, which enhance their income earning capacity, and improve their living standard [20]. Maruod study was conducted to investigate the role of North Kordofan
Rural Development Project (NKRDP) as a microfinance institution in women development, in Bara Locality. The results showed that $80 \%, 96.3 \%, 60 \%, 63.8 \%$ and $65 \%$ of the respondents mentioned that the project helped in providing education services, health services, water services, fuel services and handcrafts respectively. Results also showed that about $91.25 \%$ of the respondents had got profits from their investments.

Within the internal context, a survey for the collection of data on Islamic microfinance in the Arab region was conducted by Sanabel show that Sudan holds $70 \%$ of Islamic microfinance within the Arab region. CGAP [21], described Sudan Islamic microfinance model as: A laboratory for Islamic microfinance delivery where developments could shed light on effective Islamic microfinance practices. The IMF Sudan Article of Consultation, Sep. 2013, stated that "The microfinance sector is small but growing rapidly. The results of this push have been impressive to date. In terms of active clients, Sudan \& Bangladesh are easily the global leaders in Islamic finance microfinance, with Sudan likely to take top spot given current growth rates". Issa et al. mapping exercise of Islamic banking/institutions in Africa, reveals that over $40 \%$ of these institutions are located in Sudan which imposes compliance with Shariah on the entire financial sector [22,23]. Within the three top countries with the highest Islamic microfinance outreach, two institutions dominate: (i) in Sudan the Agriculture Bank serves 75 percent of clients using Sharia-compliant products and (ii) in Bangladesh, the Islamic Bank of Bangladesh serves 67\%. Task Team Leader Andres, Economist and Country Sector Coordinator with the World Bank say that "I have never seen a country so committed to microfinance as Sudan. The microfinance sector is growing in Sudan and it seems to be a healthy sector compared to other countries where the sector grows and then begins to drop."

\section{Challenges of Islamic microfinance in Sudan}

However, in spite of its successes, microfinance in Sudan has barely scratched the surface of need .Nonetheless late statistics show that the total number of clients in 2014 is 970,000 i.e. $8 \%$ coverage of total polemical clients (estimated at 7.2 mill.). Leaving more than 6 million individuals in Sudan have a need of microfinance services. This was also supported by the World Bank recent survey conducted in urban areas (state of Khartoum), showing that 1.5 million people-21\% of the total population-expressed interest for such loans. Yet at the same time, $72 \%$ of the micro entrepreneurs surveyed said they had no access to formal or informal credit services [1]. In the same vein according to Asli Demirguc [24] 92\% of the Sudanese adults who report having used mobile money in 2011do not have a formal account, $7 \%$ of adults have an account with formal financial institutions, $3 \%$ have saving with formal financial institutions, $2 \%$ get loans during 2011 from formal financial institutions, and only $1 \%$ have a credit card. This might be due to several reasons briefed below.

1. Sudan microfinance market maintains a high operating expense ratio at 56\% (Situational Analysis 2006). Equally, for MFPs, the cost of reaching people is high. The lack of physical infrastructure increases the transaction costs for micro- and small enterprises. In addition, limited market information flows discourage market entry and formalization, particularly for subsistence farmers and rural micro entrepreneurs. Equally, for MFPs, the cost of reaching people is high. Distance of microfinance institutions [25]: is a variable that is always associated with high transaction costs. Time gaps to receive loans are 53, 59 and 86 days in Um Rwaba, Shiekan and Enuhud localities, respectively. These long time gaps have encouraged many borrowers to 
drop out after one cycle of credit or not to ask for credit in the future [25].

2. There is no sustainable, i.e. profitable, microfinance model for the rural areas, which constitute about $90 \%$ of the geographical area of Sudan, mainly due to the lack of road and transportation infrastructure, lack of market access, lack of business skills and recurring conflicts [26]. Banks do not specifically target the rural poor [27]. The weakness on basic infrastructure represents big challenge, which hinders Islamic microfinance institutions to reach the poor in the very remote areas. the poor communication, and the weakness of the Sudanese basic infrastructures, microfinance providers deliberately ignoring the rural areas clients' because of the high risk/cost, only $20 \%$ of the available microfinance resources appear to be reaching the rural areas which have $80 \%$ of the microfinance market. Moreover, putting in mind the nature of Islamic finance such as Al-salam and Istisna'a in to consideration, the availability of warehouses and cheap in-land transportation are even more essential [28].

3. Limited range of microfinance products being focusing on micro loans for productive purposes only [29].

4. The diversity of Islamic microfinance beneficiaries in Sudan in terms of the geographical rural areas, climates, tribalism system, farms and non-farms based activities, livestock, trading, religious and the political climate need well trained microfinance providers staff to deal with different issues at the same times [28] most of Islamic microfinance providers currently active in Sudan are by international standards small and display serious weaknesses in operational, financial, managerial and strategic management capabilities [13].

5. Although there are many Islamic modes of finance, Murabaha seems to be the favoured mode for many providers, even though it might not be the most suitable for some clients and their projects. UNICONS (Situational analysis 2006) study show that the lending methods used by all organizations and institutions engaged in micro-credit are Murabaha (40\%), Quardhasan (17.6\%), hirepurchase (14.5\%), Salam (10\%) and Mudaraba (3.7\%). Although CBOS directive places a ceiling of 30 per cent of the loan portfolio to be dedicated to murabaha and at the same time restricts the profit margin on murabaha contracts to a maximum of 9\% [30]. Darfur [31] study revealed that the vast majority of microfinance loan products are traditional murabaha, Impact Evaluation [32] show that majority of clients (87.1\%) have Murabaha as their Islamic mode of finance for their microfinance loan, while other modes of finance account for less than 5\% each. As noted by Ibrahim in Crossfire [33] current practice of Islamic banking worldwide is heavy dependent on murabaha which is similar in practise, but not in principle to interest rate, might not be a suitable formula to combat poverty and profiting from the poor.

\section{Conclusion and Implications}

This study demonstrated Sudan's experience in implementing Islamic principles in developing Islamic microfinance. It has shown the financial models practiced in Sudan compared with the conventional microfinance models in general and those practice in the Muslim world in particular. The paper also, highlighted the Islamic microfinance implemented in Sudan and showed the shortcomings in these projects to be solved by taking the experiences of other countries into consideration.

Based on the aforementioned studies, this study concludes that there are a lot of opportunities for Islamic microfinance in Sudan and other Muslim countries if governments and regulators paid attention to the business model and profit and loss share products.

\section{References}

1. Banker Africa Issue (2014) 010.CPI Financial.

2. WDI (2013) World Development Indicators of the World Bank, Washington DC USA.

3. (2012) Mapping, Capacity Assessment and Capacity Development of Microfinance Providers in Sudan.

4. Khan AA (2011) What role for Islamic finance in promoting development? Paper presented at the Institute of Social Studies, Netherlands.

5. Badr EDAI (2013) Islamic Microfinance-Why is it worth considering? Posted by Microfinance Nigeria, J Islam Banking Finance 30: 98.

6. IFC (2007) Syria Microfinance Market Assessment, Draft Report. Washington DC:IFC/The World Bank.

7. IFC/FINCA (2006) Business Plan for a Microfinance Institution in Jordan, Commissioned by IFC and FINCA.

8. (2006) Frankfurt School of Finance and Management (Bank akademia International), Access to Finance in Algeria, Final Report. Frankfurt: Frankfurt School of Finance and Management, Algeria.

9. Salwana H, Abdul Rahman R, Abu Bakar N, Mohd R, Muhammad AD, et al. (2013) Designing Microfinance Products for Islamic Banks in Malaysia, MiddleEast Journal of Scientific Research 17: 359-366.

10. Riwajanti NI (2013) Islamic Microfinance as an Alternative for Poverty Alleviation: A Survey Afro Eurasian Studies 2: 254-271.

11. Shabrawy EA (2011) Innovation in Micro Entrepreneurship and Islamic Microfinance the model of Family bank in Bahrain, 10th International Entrepreneurship forum, Bahrain 1-18.

12. Mohsin S (2011) Overview of Microfinance. Education, Economy and Finance, Technology, International Conference on Islamic Microfinance, US.

13. Abukasawi MG, Hasssan Al (2006) Situational Analysis of the Microfinance Sector in Sudan Unicons.

14. (2013) Impact Evaluation Assessment MFI Sector in Sudan 2007-2012 Sudanese Microfinance Development Facility (SMDF) Draft Report, PACT, Sudan.

15. Badr EDAI (2014) Microfinance Sectors in two African countries-Sudan and Ethiopia, AEMFI $8^{\text {th }}$ biennial conference, Hawassa, Ethiopia.

16. (2008) Unicons Evaluation of Implementation of the Strategy For Expansion and Development of The Micro Finance Sector In Sudan.

17. IFAD (2012) Islamic microfinance: Unlocking new potential to fight rural poverty From a market niche to a growing industry, Italy.

18. Amira YB (2013) The Role of Micro-credit System for Empowering Poor Women, Developing Country Studies 3: 71-84

19. Elmola SF, Belal I (2013) The Impact of Microfinance on Rural Poor Households Income and Vulnerability to Poverty: Case Study of North Kordofan State Tropentag 17-19.

20. Habeeb EEH, Maruod EM, Mohammed SE (2014) The Role of North Kordofan Rural Development Project (NKRDP) in Women Development in Bara locality, North Kordofan State. Int J Edu Res 2: 39-52.

21. CGAP (2008) Islamic Microfinance: An Emerging Market Niche, Focus Note No. 49.

22. Badr IEDA (2014) President, Microfinance Unit, Successful Models in Agricultural Microfinance Sponsored by the Central Bank of Sudan, (CBoSCTAAFRACA) Revolutionizing finance for agri-chain 14-18.

23. Faye I, Triki T, Kangoye T (2013) The Islamic finance promises: Evidence from Africa. Review of Development Finance 3: 136-151.

24. Demirguc KA, Klapper L (2012) Measuring Financial Inclusion, The Globa Findex Database. The World Bank Development Research Group Finance and Private Sector Development Team.

25. Ibrahim AH, Bauer S (2013) Access to Micro credit and its Impact on Farm Profit among Rural Farmers in Dryland of Sudan, Global Advanced Research Journal of Agricultural Science 2: 088-102. 
26. (2006) Unicons: A Vision for the Development and Expansion of the Microfinance Sector in Sudan.

27. Sinha S (2007) Microfinance Consultant, IFAD-First National Consultative Forum on Microfinance in Sudan.

28. Ali ASE (2013) The Challenges of Islamic Trade Finance in Promoting SMEs In IDB Member Countries, Central banks of Sudan reports, J Eur Sci.

29. (2010) Evaluation report, The Savings and Social Development Bank SSDBUNICONS, Sudan.

30. Laura A (2009) Government of Sudan Issues Directives Requiring Banks to Allocate 12 Percent of Portfolio to Microfinance, Sudan.
31. Badr IEDA (2014) Sudan-Enabling Policies, Supervisory and Regulatory Framework for Microfinance Sector, Roundtable Discussion on Regulatory and Supervisory Framework in Islamic Microfinance, Idb, Sudan University Of Science and Technology, Khartoum.

32. (2013) Country Programming Framework for Sudan "Plan of Action (2015 2019)" Resilient Livelihoods for Sustainable Agriculture, Food Security and Nutrition, FAO Representation in Sudan Khartoum.

33. (2013) Trends in Sharia-Compliant Financial Inclusion", Consultative Group to Help the Poor, CGAP, The World Bank, Focus Note. 